\author{
A.S. Shagyrbay* ${ }^{(i)}$ L.Zh. Ashirbekova \\ Al-Farabi Kazakh National University, Higher school of economics and business, Kazakhstan, Almaty \\ *e-mail: aidanshsb@gmail.com
}

\title{
IMPACT OF THE PANDEMIC ON DIGITAL MANAGEMENT: A BYBLIOMETRIC ANALYSIS
}

\begin{abstract}
Digital management is developing every year. The number of studies related to digital management is also increasing. Digital management contributes to the development of new markets and sectors of the economy, stimulates innovation and ensures productivity growth. It also brings significant changes to the organization, its processes and all areas.

Using tools and trends in digital management, many foreign organizations are making great strides. In the context of continuous information development, managers need to process large volumes of external information and use digital governance tools to stay on top of innovation. The use of digital management tools opens up new opportunities for all organizations and allows to create business processes taking into account an actively changing environment.

Currently, we can observe how digital transformation is taking place in all areas. The purpose of this research work is to conduct a bibliographic analysis of the digital management literature.

The research consists of two stages: descriptive - bibliographic analysis and content analysis. The research work analyzes and compares studies conducted in 2017-2019 and 2020-2021 related to digital management. A review of digital management research based on Scopus is carried out. In general, 1682 studies in the field of digital management were analyzed for 2020-2021. Their indicators were described by the program VosViewer. In addition, the worldwide pandemic has also had a significant impact on the development of digital management. In this regard, 49 conducted research works were identified. In the future, digital management research still needs to be deeply studied.
\end{abstract}

Key words: digital management, digital transformation, digital technologies, COVID-19.

\section{Introduction}

The use of digital technology has included in many organizations. There are many advantages to using modern technology. This allows organizations to greatly simplify their work and increase the speed of work. However, the application of such technologies must be carried out through an appropriate management process. The development of digital management is associated with the digitalization transformation of all industries in the world. Even in many countries great attention is paid to digital transformation, many programs and projects are being created.

In December, 2019, Wuhan, Hubei province, China, became the centre of an outbreak of pneumonia of unknown cause, which raised intense attention not only within China but internationally. By Jan 7, 2020, Chinese scientists had isolated a novel coronavirus $(\mathrm{CoV})$ from patients in Wuhan (Wang, et al., 2020).

The pandemic, which is now widespread around the world, has also had its impact in accelerating this digital transformation. Organizations have begun to actively deploy many digital tools to continue their work.
To maintain productivity and efficiency, COVID-19 has impacted the immediate adoption of digital technologies that accelerate communication, data collection, research and development and management by millions of people, students and employees (Kamal, 2020).

In line with the new changes caused by the pandemic, research has begun to facilitate changes in companies and find alternative solutions (Carracedo, 2020).

Accordingly, the aim of the article is to examine how the pandemic has impacted digital management using bibliographic network analysis.

Research questions

RQ 1 Has there been a change in scientific publications and digital management literature due to the pandemic?

RQ 2 What areas of research have emerged since the start of the pandemic?

\section{Literature review}

Digital management is the provision of publicly available types of assistance based on uniformity and equality between people through electronic means at 
any time and in any place, the management of structurally complex systems based on new knowledge, the solution of new problems and the use of special software (Al-Thoblany, 2021, Solozhentsev, 2020).

Digital management is understood as an enterprise management system created based on new digital technologies (or at least with their use) and capable of ensuring an increase in the efficiency and effectiveness of financial and economic activities of an enterprise and obtaining new economic benefits that are not fully available when using traditional systems and methods of management (Mikhnenko, 2020).

Even before the Covid-19 pandemic, digital technologies and their usefulness in the business environment aroused great interest. However, this interest has intensified with the advent of COVID-19. The pandemic has necessitated an increase in the use of digital devices. The widespread use of modern digital technologies raises awareness of their importance in society, especially for business purposes (Ratten and Jones, 2021).

While the pandemic is affecting the development of digital use, working digital may not bring lasting benefits to organizations.

An analysis of the use of digital technologies during a pandemic was carried out using multi-wavelength data collected through a survey of managers and employees of the hospitality industry in China. According to the study, the authors noticed that if digital governance is not properly managed, it will have a negative impact on organizations (Chadee et al., 2021).

Mora Cortez and Johnston used the TIU method in their research work, conducting a survey that included ideas that several participants considered relevant and how they relate to each other. As a result, an overwhelming majority of respondents admitted that digital transformation was relatively underdeveloped due to the pandemic in their companies (Mora Cortez and Johnston, 2020).

There are also studies on the importance of digital management tools in the fight against the pandemic. According to Bernd W. Wirtz, digital technology offers innovative, unprecedented and revolutionary opportunities to prevent the spread of a pandemic and manage an emerging crisis. However, some countries still rely on non-digital methods that are not up to date. This creates problems with detection, virus tracking, reporting, information sharing and resource management processes that may not be able to withstand the global spread of the pandemic (Wirtz et al., 2020).

The pandemic has demanded the digital transformation of all industries. The challenges posed by COVID-19 have begun to be addressed with digital tools. However, a lot of research is still required to find out how the COVID-19 pandemic can take digital thinking. In addition, additional research related to politics and the public can more accurately determine the impact of the COVID-19 crisis (Ratten, 2021).

The purpose of the article is to detect changes in research on digital management since the beginning of the pandemic. By reviewing the literature, it turned out that there are very few authors who have studied this topic.

\section{Methodological approach}

This article is a review of the digital management literature. The bibliometric analysis was conducted using data from the Scopus database. The general database contains 102331 studies of digital management. The first paper related to digital management on the Scopus database was published in 1979.

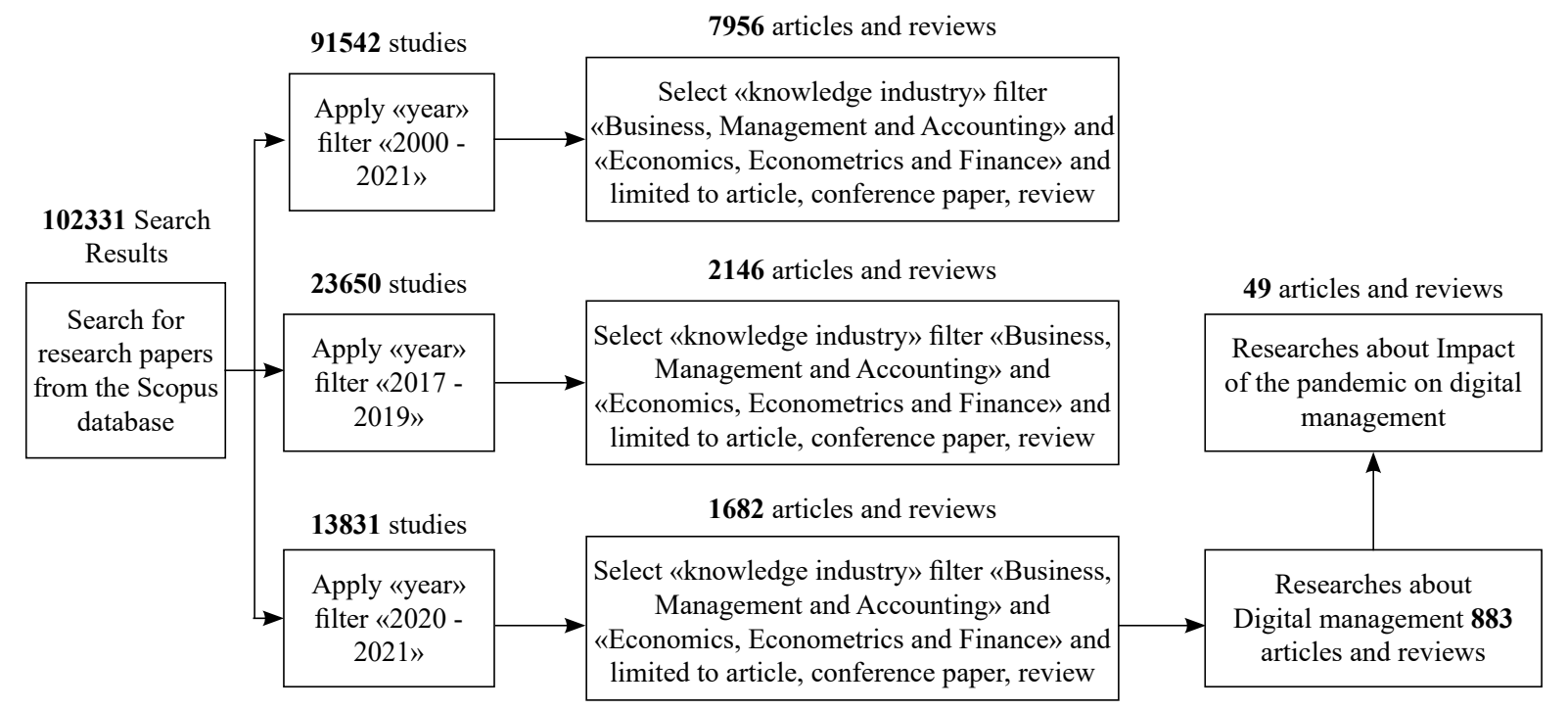

Figure 1 - Digital management research analysis scheme 
Research consists of 2 stages:

1 descriptive - bibliographic analysis. There are 2 time slots selected: 2017-2019 and 2020-2021. The reason we chose this time frame is to determine what changes have occurred in digital management research since the beginning of the pandemic.

First of all, we need to determine the level of development of digital management research based on Scopus. To do this, we can choose the period between 2000 and 2021 and see how the number of digital management research will grow every year.

We consider articles in the Scopus database in 2017-2019 and 2020-2021 by knowledge industries and chose Business, Management and Accounting and Economics, Econometrics and Finance.

We also compared coutries that have conducted digital management research.

We were looking for the items on digital management for 2017-2019 and 2020-2021. Based on the results, items analysis was carried out through the Vos Viewer.
2 content analysis - After sifting 1682 articles, we have selected 883 articles that are directly related to the topic. Of all the research papers on digital management, 49 articles were identified on the impact of the covid-19 pandemic on digital management.

\section{Results \\ Results of the bibliographic analysis}

We selected 2000-2021 to monitor the development of digital management researches every year and determined how much research was conducted based on Scopus during this period. During this period, 91542 research papers were written. 7956 of them are related to the Business, Management and Accounting (7458) and Economics, Econometrics and Finance (1435) industries.

We can see that the amount of digital management researches increasing every year.

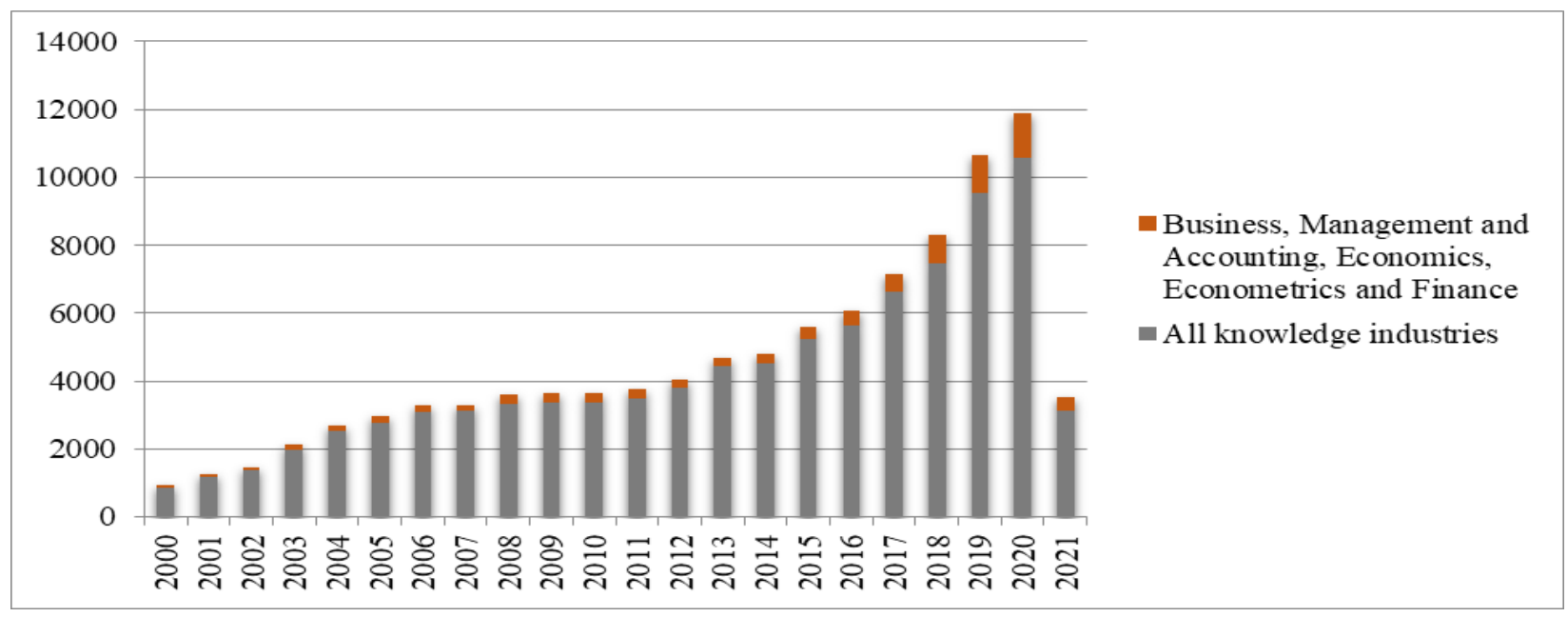

Figure 2 - Development of research on digital management

In 2017-2019, 23650 digital management-related studies were conducted. The vast majority of them were conducted in the fields of Computer Science 10481, Engineering 7910, Medicine 3493. In the Business, Management and Accounting 2304, Economics, Econometrics and Finance 491 researches were conducted.

In 2020-2021, 13831 studies were conducted. The most frequently studied areas are Computer Science (5238), Engineering (4555) and Medicine (2394). In addition, research was conducted in the fields of
Business, Management and Accounting (1501) Economics, Econometrics and Finance (382). We can see that there is not much difference in the studies conducted between the two stages.

The country with the largest number of studies in 2017-2019 is the Russian Federation. There were 301 studies conducted in this country. Also, the top-10 research countries include the United States (261), Germany (224), United Kingdom (179), China (126), India (112), Italy (99), Australia (86), Indonesia (69), and France (66). 


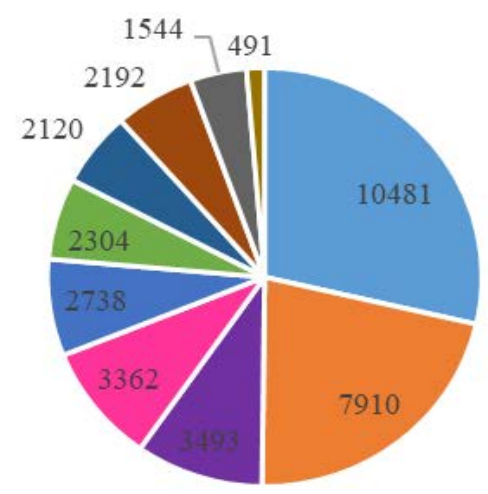

- Computer Science

- Medicine

- Mathematics

- Environmental Science

- Earth and Planetary Sciences
- Engineering

- Social Sciences

- Business, Management and Accounting

- Decision Sciences

- Economics, Econometrics and Finance

Figure 3 - Research areas of Digital Management in 2017-2019

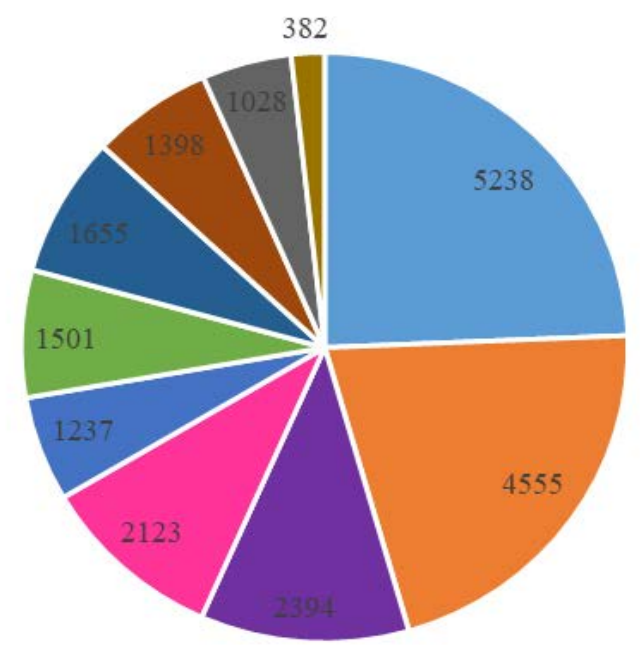

- Computer Science

- Medicine

- Mathematics

- Environmental Science

- Earth and Planetary Sciences
- Engineering

- Social Sciences

- Business, Management and Accounting

- Decision Sciences

- Economics, Econometrics and Finance

Figure 4 - Research areas of Digital Management in 2020-2021 


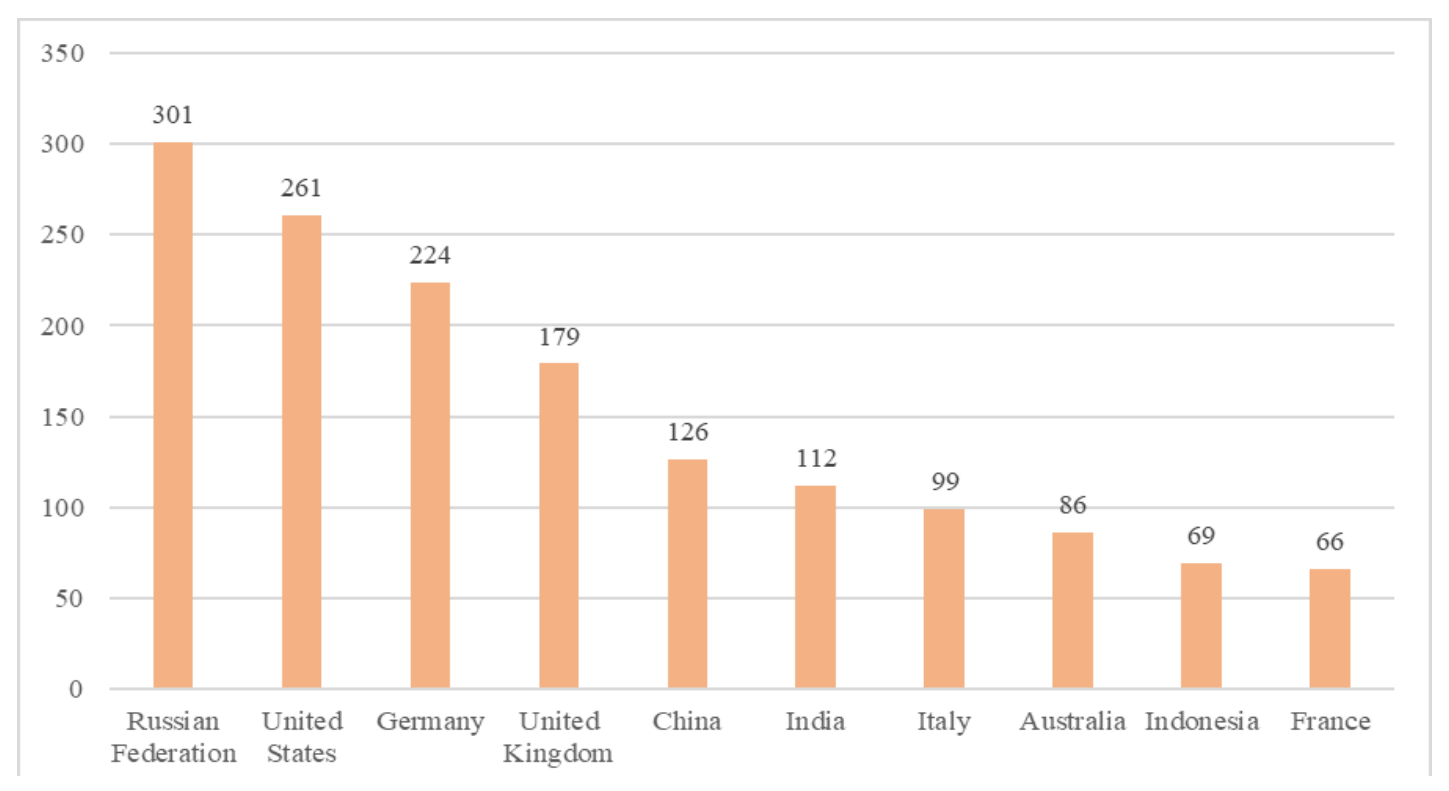

Figure 5 - Top-10 research countries in 2017-2019

And according to the indicators of 2020-2021, we can see that the United States is in first place. Also in Italy, the number of studies has increased compared to China and India. Changes were also observed in France and Indonesia. In general, the countries of the top-10 in terms of research volume have not changed.

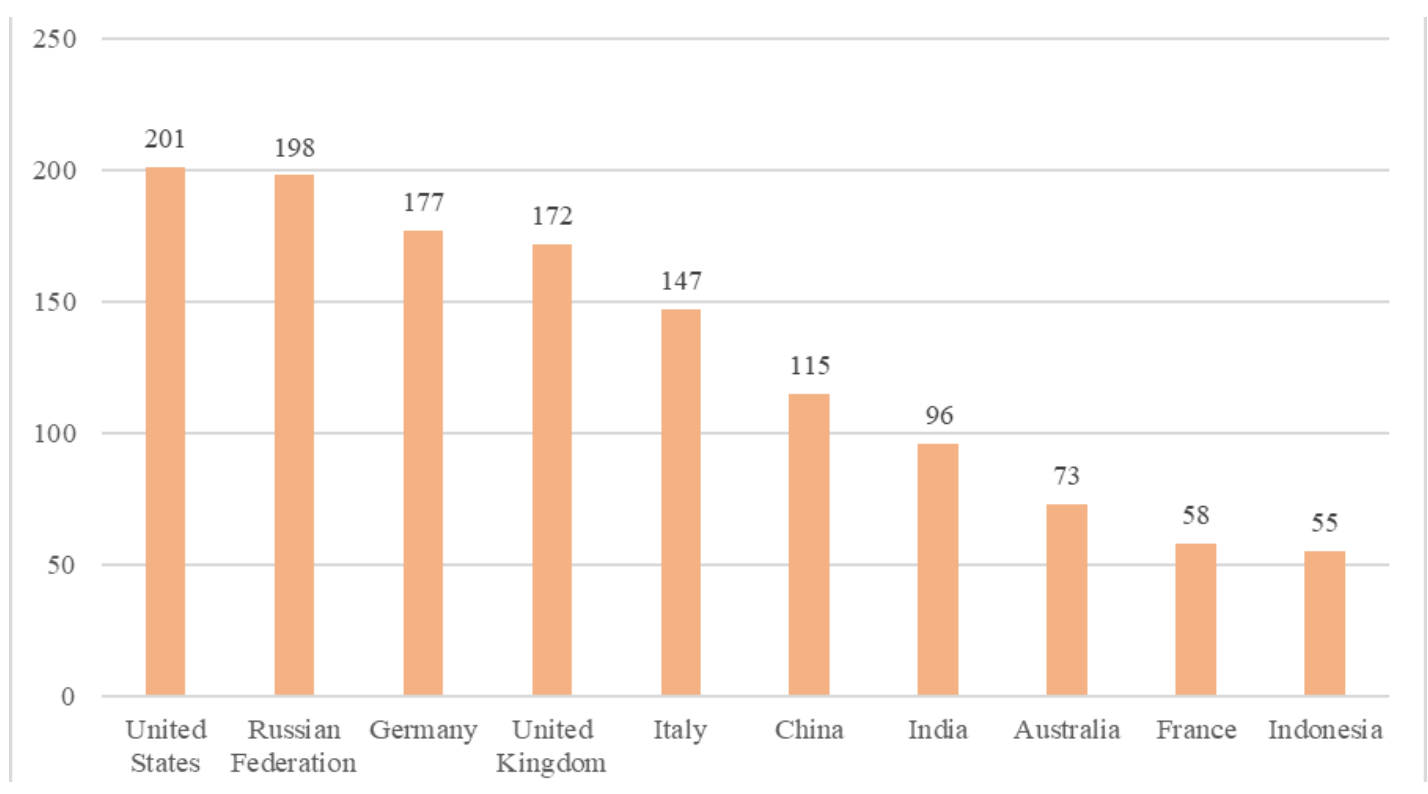

Figure 6 - Top-10 research countries in 2020-2021

Overall, we can observe how digital management research is developing in all areas every year. We were able to determine it by the above comparisons.
We analyzed research papers from 2017-2019 about digital management and selected 2146 documents. With the VosViewer program, we found 6 clusters and 140 items. 


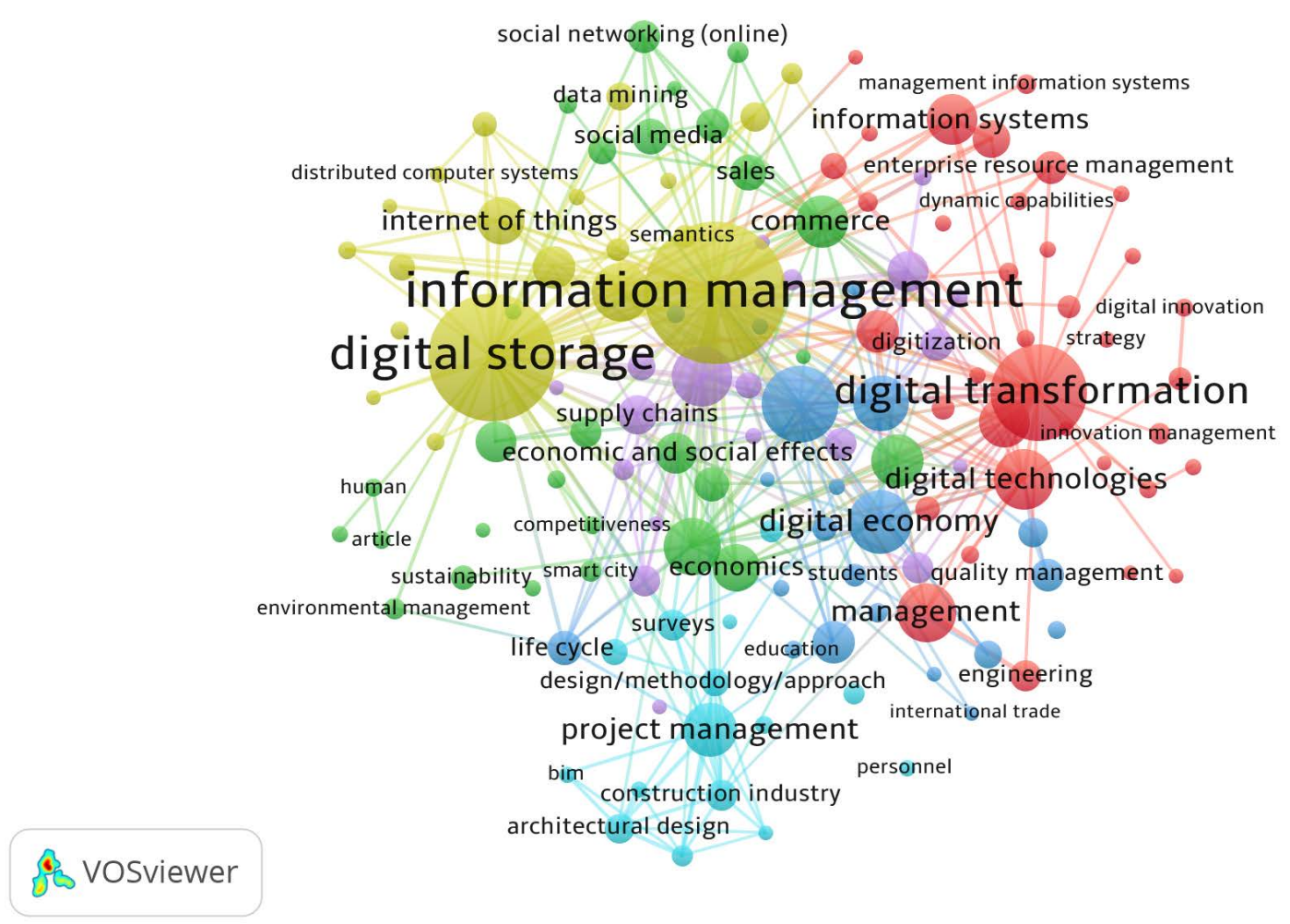

Figure 7 - Research keywords in 2017-2019 (Vos Viewer)

Cluster 1 consists of 36 items. It has «business process management», «change management», «enterprise resource management», «industrial management», «innovation management», «management information systems» keywords and shows an important role of digital management.

Cluster 2 has 28 items and includes different industries like «design», «e-commerce», «digital marketing» and development advantages such as «technological development», «sustainable development».

In cluster 3 we found 21 items. Most of them about modern education. There are keywords like «digital libraries», «e-learning», «higher education», «education», «students». With digital management distance learning can be facilitated.
Cluster 4 consists of «artificial intelligence», «big data», «blockchain», «internet of things», «digital storage», «cloud computing» and other 21 items. There are the main tools and trends of digital management.

Cluster 5 shows competition advantages of digital management in organisations and has 19 items. It includes «analog to digital conversion», «competition», «decision making», «costs», «efficiency», «optimization», etc.

In Cluster 615 items. Research papers in this cluster have keywords such as «building information modelling», «construction industry», «information and communication technologies», «planning», «strategic management», «project management» and shows how to realize digital management.

Table 1 - Digital Management Research Clusters 2017-2019

\begin{tabular}{|c|c|c|}
\hline Cluster & Name & Number of items \\
\hline Cluster 1 (red) & Digital transformation of management & 28 \\
\hline Cluster 2 (green) & Digital management and other areas & 21 \\
\hline Cluster 3 (deep-blue) & Digital management and education & 21 \\
\hline Cluster 4 (yellow) & Digital management tools and trends & 19 \\
\hline Cluster 5 (violet) & Competitive advantages of digital management & 15 \\
\hline Cluster 6 (bright-blue) & Development of digital management & \\
\hline
\end{tabular}


Figure 8 shows the authors' keyword matching line for the Digital management research paper. Analyzing

9250 keywords of 1682 documents in the Scopus base, we select 7 clusters out of 102 items through VOSviewer.

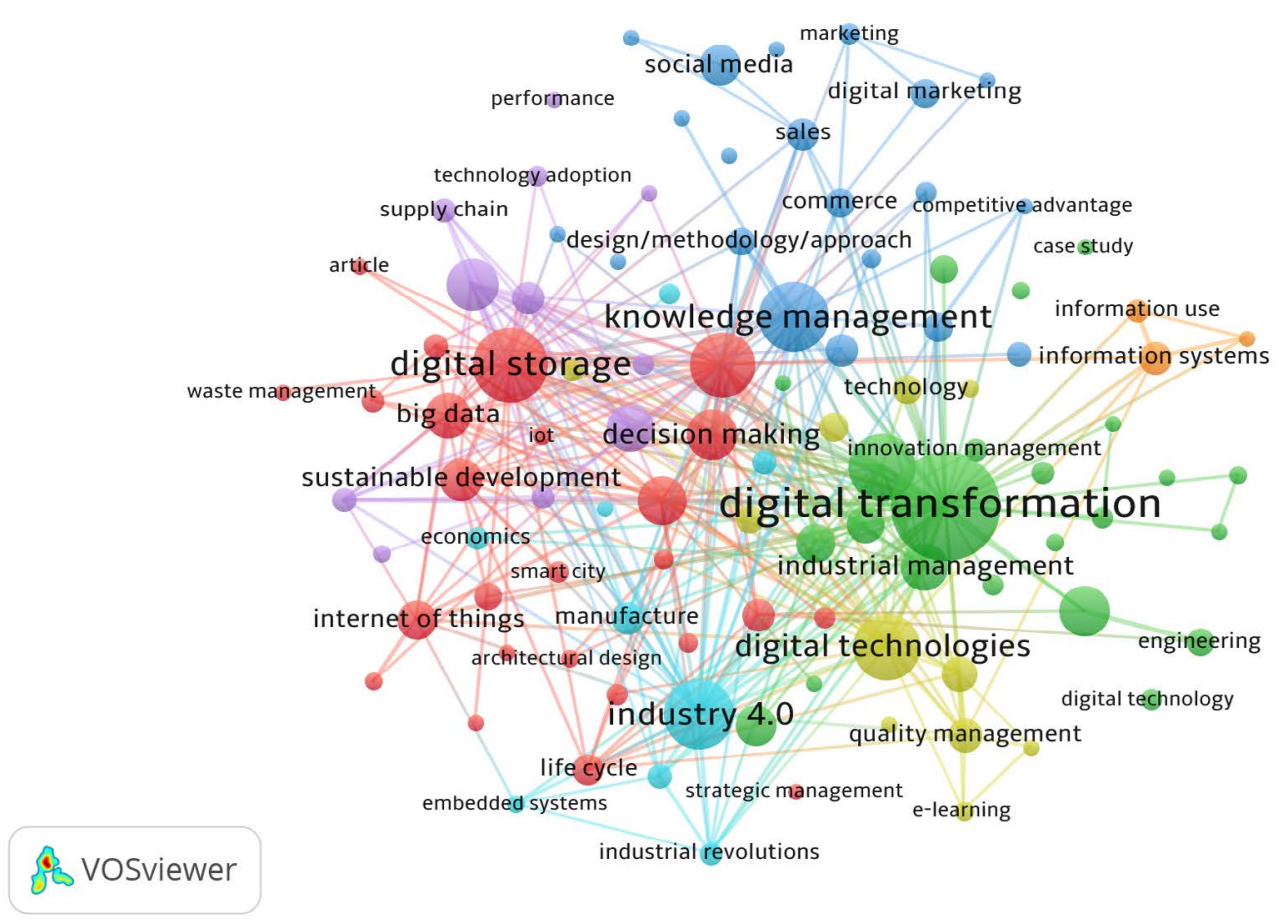

Figure 8 - Research keywords in 2020-2021 (Vos Viewer)

Cluster 1 consists of 25 items. Digital management includes the keywords: «artificial intelligence», «internet of things», «big data», «digital storage», «digital twin». This is the main tools of digital management.

Cluster 2 has 23 items and includes research papers on how to realize digital management. There are keywords like «digital transformation», «digital business», «digitalisation», «digital economy», «digital innovation». In addition, we can observe the emergence of a new keyword in this cluster. Since the beginning of the pandemic, research has also begun on «Technological innovation» related to the massive transition to digitalization.

Cluster 3 consist of 20 items. There are articles related to industries in which management can be developed. In articles frequently used keywords are «marketing», «sales», «commerce», «design», «electronic commerce».

In Cluster 4 research papers on COVID-19 appeared. There are 11 items. This cluster contains the keywords «COVID-19», «e-learning», «quality management», «risk management», «digital technologies».

Cluster 5 has 11 items. There are such keywords as «supply chain management», «data management», «literature review». In this cluster, we also defined a new keyword. The beginning of research on «Technology adoption» can be linked to the emergence of digital transformation in all industries.

Cluster 6 shows research papers about Industry 4.0. It includes key words like «Industrial research», «industrial revolutions», «Inductry 4.0.», «economics». This demonstrates the importance of the role of digital management in Industry 4.0.development.

The last Cluster 7 has 3 items: «information systems», «information use», «management information systems». This indicates a link between digital management and information systems.

«Vos Viewer» was used to determine the difference between the 2017-2019 and 2020-2021 articles. As a result, we noticed that some changes have occurred. Since the beginning of the Covid-19 pandemic, studies of the impact of the pandemic have begun to be conducted in research in the field of digital management. In addition, using the words» technological innovation», «technology implementation», you can see that the pandemic has influenced the acceleration of the use of technology. 
Table 2 - Digital Management Research Clusters 2020-2021

\begin{tabular}{|c|c|c|}
\hline Cluster & Name & Number of items \\
\hline Cluster 1 (red) & Digital management tools and trends & 25 \\
\hline Cluster 2 (green) & Digital transformation of business & 23 \\
\hline Cluster 3 (deep-blue) & Digital management in different areas of business & 20 \\
\hline Cluster 4 (yellow) & Digital management and pandemic & 11 \\
\hline Cluster 5 (violet) & Literature review & 9 \\
\hline Cluster 6 (bright-blue) & Digital management and Industry 4.0 & 3 \\
\hline Cluster 7 (orange) & Information systems of digital management & 11 \\
\hline
\end{tabular}

\section{Results of the content analysis}

Of the 1682 studies conducted in 2020-2021, 883 studies related to digital management were selected. Among them, the vast majority are studies on the topics of tools and trends of digital management, digital trans- formation, digital innovation. They also considered studies related to the impact of the pandemic on the development of digital management of organizations. 49 articles on this topic have been researched. In addition, research has been conducted related to digital management in areas such as education, healthcare, marketing, etc.
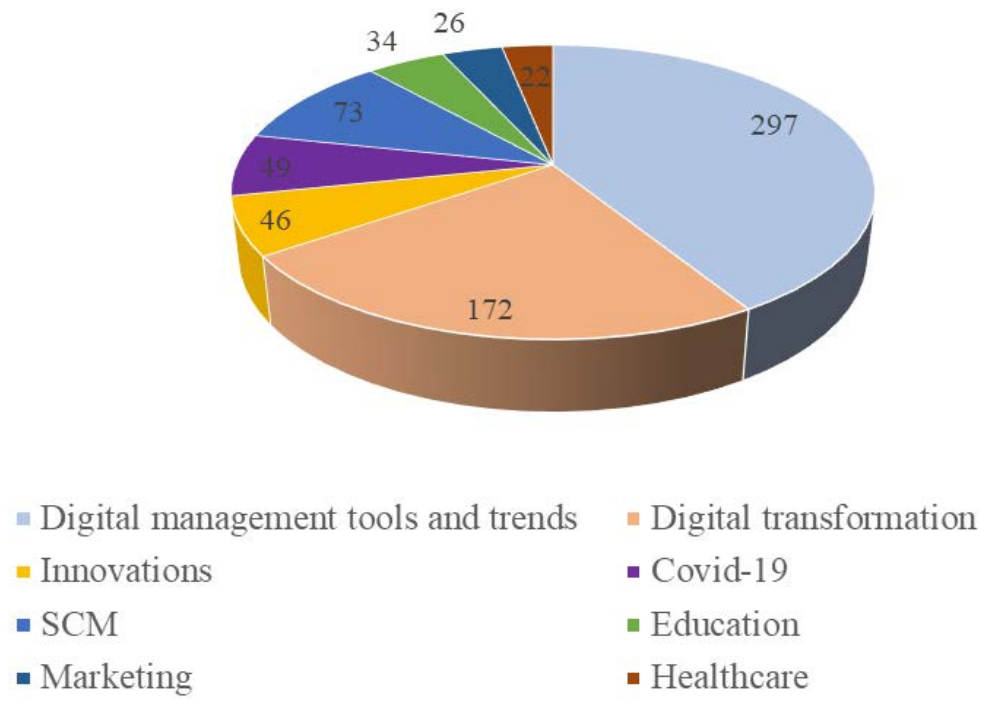

Figure 9 - The most studied topics in 2020-2021

The most common of research fields are digital management tools, digital transformation, digital innovation, supply chain management, COVID-19. They are the most relevant topics in the field of digital management. In these studies, the most pressing issues of digital management, future research directions, and development opportunities are considered. We got acquainted with some literature on these topics.

Table 3 - Digital Management research topics in 2020-2021

\begin{tabular}{|l|l|l|}
\hline \multicolumn{1}{|c|}{ Research field } & \multicolumn{1}{c|}{ Authors } & \multicolumn{1}{c|}{ Notes } \\
\hline $\begin{array}{l}\text { Digital management tools } \\
\text { and trends }\end{array}$ & $\begin{array}{l}\text { Rani and Furrer, 2021; Sinha and } \\
\text { Pradhan, 2021; Haefner et al., 2021; } \\
\text { Sestino et al., 2020; Lindorfer, 2020. }\end{array}$ & $\begin{array}{l}\text { The articles studied the use of digital management tools in } \\
\text { organizations by questioning employees. An analysis was } \\
\text { also carried out of state and business management using } \\
\text { digital management tools such as blockchain, artificial } \\
\text { intelligence, Internet of Things etc. }\end{array}$ \\
\hline
\end{tabular}


Continuation of table 3

\begin{tabular}{|c|c|c|}
\hline Digital transformation & $\begin{array}{l}\text { Nadkarni and Prügl, 2021; Nell et al., } \\
\text { 2021; Appio et al., 2021; Marion and } \\
\text { Fixson, 2021; Shahi and Sinha, 2021; } \\
\text { M., Wrede et al., } 2020 .\end{array}$ & $\begin{array}{l}\text { A review of the literature on digital transformation was } \\
\text { carried out, directions of research in the future were } \\
\text { identified. During the digital transformation, managers were } \\
\text { interviewed to find out what traps (barriers) will exist, to } \\
\text { find out how the digital transformation process is being } \\
\text { carried out. The links between innovation management } \\
\text { and digital transformation, changes in the process of } \\
\text { digital transformation over the years, the impact of digital } \\
\text { transformation on the work of an organization, etc. are } \\
\text { analyzed. }\end{array}$ \\
\hline COVID-19 & $\begin{array}{l}\text { Caballero-Morales, 2021; } \\
\text { Ratten and Jones, 2021; Ratten, 2021; } \\
\text { Ahmad et al., 2021; Klein and Todesco, } \\
\text { 2021; Casalino et al., 2020. }\end{array}$ & $\begin{array}{l}\text { To determine how the internal and external factors caused by } \\
\text { the COVID-19 pandemic are affecting digital transformation, } \\
\text { a management focus group was created and a qualitative } \\
\text { analysis was carried out. The role of digital transformation } \\
\text { during and after the pandemic was examined using a SWOT } \\
\text { analysis. }\end{array}$ \\
\hline Innovations & $\begin{array}{l}\text { Endres et al., 2021; Wiesböck and } \\
\text { Hess, 2020; Manotti et al., 2020; } \\
\text { Glinkina et al., } 2020 .\end{array}$ & $\begin{array}{l}\text { The research papers focused on digital management of } \\
\text { innovation processes and tools for its implementation. } \\
\text { Directions for further exploring digital innovation were } \\
\text { shown. } \\
\text { A bibliographic analysis of digital innovation research has } \\
\text { been carried out. This study used the methods of a systems } \\
\text { approach, as well as statistical and economic analysis. }\end{array}$ \\
\hline $\begin{array}{l}\text { Supply chain } \\
\text { management }\end{array}$ & $\begin{array}{l}\text { Nürk, 2021; } \\
\text { Benzidia et al., 2021; Choudhury et } \\
\text { al., 2021; } \\
\text { Yousif Alsharidah and Alazzawi, 2020; } \\
\text { Yankovskaya et al., 2020; Ageron et } \\
\text { al., 2020. }\end{array}$ & $\begin{array}{l}\text { A qualitative approach was used to explore new } \\
\text { opportunities emerging in supply chain management through } \\
\text { digitalization, a literature review, an online survey. A study } \\
\text { was carried out on digital transformation and the use of } \\
\text { digital management tools such as artificial intelligence, big } \\
\text { data in supply chain management. In addition, analytical data } \\
\text { related to government support for digital supply chain man- } \\
\text { agement were presented. Through the digitalization of supply } \\
\text { chain management, directions for its further development } \\
\text { were developed. }\end{array}$ \\
\hline
\end{tabular}

Research related to digital management is used in various directions. The most common studies among them are articles about tools and trends of digital management and digital transformation. Based on the research results, these articles can be used in future additional research.

\section{Discussion}

The purpose of the article was to identify changes in digital management research since the beginning of the pandemic. To achieve this goal, we chose 2017-2019 as the pre-pandemic period and compared the studies carried out during this period with the studies carried out in 2020-2021.

After analyzing the research in two stages, we observed that there have been some changes in the research works on digital management.

First of all, with regard to the volume of research, the number of studies on digital management is constantly increasing every year. Despite the pandemic, this figure is increasing. Even from the start of the pandemic, new challenges have arisen for digital management research.

There have been no major changes in the industry of knowledge. In both phases, digital management research was conducted in the same areas.

There is little change in the countries that have conducted the digital management study.

To identify changes by keywords, we worked with the Vos Viewer program. Since the beginning of the pandemic, we have discovered the emergence of new keywords: «technological innovation», «COVID-19», «technology adoption». During the Content Analysis, we reviewed articles written to study the impact of the pandemic on digital management. The articles investigated the role of digital management in the fight against a pandemic, digital transformation in organizations during a pandemic, etc.

\section{Conclusion}

The aim of the research work is to review the literature related to digital management, and to identify 
the links of digital management with other industries, to analyze the development of digital management research. For this purpose, research work at the Scopus database was considered. In particular, a review of studies between 2017-2019 and 2020-2021 was carried out, and the features of their studies were compared.

The most common keywords were identified and described on the map using the VosViewer. In recent years, there has been an increase in the amount of research related to digital transformation and digital technologies. In 2020, due to the widespread pandemic, the number of studies conducted to analyze the impact of the Covid-19 virus on digital management began to grow.
Although the number of digital management research is constantly increasing, the vast majority of it is research in areas related to digital management, or the digitalization of these areas. Questions about real digital management, about the impact of the pandemic on its development, currently still need to be studied.

Research should continue in the future on the impact of the Covid-19 pandemic on digital governance. The amount of research conducted on this topic is not very much.

According to the proposed bibliometric analysis, it is possible to conduct research in these and various other areas.

\section{References}

Ageron, B., Bentahar, O., \& Gunasekaran, A. (2020). Digital supply chain: Challenges and future directions. Supply Chain Forum, 21(3), 133-138. doi:10.1080/16258312.2020.1816361

Al-Thoblany, M. S., \& Alyuosef, M. I. (2021). The role of digital management in improving the performance of tourism sectors in the kingdom of saudi arabia in the light of 2030 vision. Journal of Sustainable Finance and Investment, doi:10.1080/20430795.2021.1882236

Ahmad, A., Alshurideh, M. T., Al Kurdi, B. H., \& Salloum, S. A. (2021). Factors impacts organization digital transformation and organization decision making during Covid19 pandemic doi:10.1007/978-3-030-67151-8_6

Appio, F. P., Frattini, F., Petruzzelli, A. M., \& Neirotti, P. (2021). Digital transformation and innovation management: A synthesis of existing research and an agenda for future studies. Journal of Product Innovation Management, 38(1), 4-20. doi:10.1111/jpim.12562

Benzidia, S., Makaoui, N., \& Bentahar, O. (2021). The impact of big data analytics and artificial intelligence on green supply chain process integration and hospital environmental performance. Technological Forecasting and Social Change, 165 doi:10.1016/j.techfore.2020.120557

Caballero-Morales, S. -. (2021). Innovation as recovery strategy for SMEs in emerging economies during the COVID-19 pandemic. Research in International Business and Finance, 57 doi:10.1016/j.ribaf.2021.101396

Carracedo, P., Puertas Medina, R., \& Luisa Martí Selva, M. (2020). Research lines on the impact of the COVID-19 pandemic on business. A text mining analysis. Journal of Business Research, doi:10.1016/j.jbusres.2020.11.043

Casalino, N., Zuchowski, I., Labrinos, N., Nieto, Á. L. M., \& Martín-Jiménez, J. A. (2020). Digital strategies and organizational performances of smes in the age of coronavirus: Balancing digital transformation with an effective business resilience. Law and Economics Yearly Review, 8, 347-380. Retrieved from www.scopus.com DOI: 10.2139 / ssrn.3563426

Chadee, D., Ren, S., \& Tang, G. (2021). Is digital technology the magic bullet for performing work at home? lessons learned for post COVID-19 recovery in hospitality management. International Journal of Hospitality Management, 92 doi:10.1016/j.ijhm.2020.102718

Choudhury, A., Behl, A., Sheorey, P. A., \& Pal, A. (2021). Digital supply chain to unlock new agility: A TISM approach. Benchmarking, doi:10.1108/BIJ-08-2020-0461

Endres, H., Huesig, S., \& Pesch, R. (2021). Digital innovation management for entrepreneurial ecosystems: Services and functionalities as drivers of innovation management software adoption. Review of Managerial Science, doi:10.1007/s11846-021-00441-4

Glinkina, O. V., Ganina, S. A., Maslennikova, A. V., Solostina, T. A., \& ViktorovnaSoloveva, M. (2020). Digital changes in the economy: Advanced opportunities for digital innovation. International Journal of Management, 11(3), 457-466. doi:10.34218/ IJM.11.3.2020.049

Haefner, N., Wincent, J., Parida, V., \& Gassmann, O. (2021). Artificial intelligence and innovation management: A review, framework, and research agenda $\square$. Technological Forecasting and Social Change, 162 doi:10.1016/j.techfore.2020.120392

Kamal, M. M. (2020). The triple-edged sword of COVID-19: Understanding the use of digital technologies and the impact of productive, disruptive, and destructive nature of the pandemic. Information Systems Management, 37(4), 310-317. doi:10.1080/1058 0530.2020 .1820634

Klein, V. B., \& Todesco, J. L. (2021). COVID-19 crisis and SMEs responses: The role of digital transformation. Knowledge and Process Management, 28(2), 117-133. doi:10.1002/kpm.1660

Lindorfer, B. (2020). "Management of technologies in the 21rd digital century". Paper presented at the 26th International Association for Management of Technology Conference, IAMOT 2017, 829-850.

Manotti, J., Sanasi, S., Cavallo, A., Ghezzi, A., \& Rangone, A. (2020). Digital innovation: A bibliometric review and research agenda. Paper presented at the Proceedings of the European Conference on Innovation and Entrepreneurship, ECIE, , 2020-September 369-375. doi:10.34190/EIE.20.116

Marion, T. J., \& Fixson, S. K. (2021). The transformation of the innovation process: How digital tools are changing work, collaboration, and organizations in new product development*. Journal of Product Innovation Management, 38(1), 192-215. doi:10.1111/ jpim. 12547 
Mikhnenko, P. A. (2020). Digital management: models of concept development. Innovation in management, 3 (25), $30-39$.

Mora Cortez, R., \& Johnston, W. J. (2020). The coronavirus crisis in B2B settings: Crisis uniqueness and managerial implications based on social exchange theory. Industrial Marketing Management, 88, 125-135. doi:10.1016/j.indmarman.2020.05.004

Nadkarni, S., \& Prügl, R. (2021). Digital transformation: A review, synthesis and opportunities for future research. Management Review Quarterly, 71(2), 233-341. doi:10.1007/s11301-020-00185-7

Nell, P. C., Foss, N. J., Klein, P. G., \& Schmitt, J. (2021). Avoiding digitalization traps: Tools for top managers. Business Horizons, 64(2), 163-169. doi:10.1016/j.bushor.2020.11.005

Nürk, J. (2021). Smart information system capabilities of digital supply chain business models. European Journal of Business Science and Technology, 5(2), 143-184. doi:10.11118/EJOBSAT.V5I2.175

Rani, U., \& Furrer, M. (2021). Digital labour platforms and new forms of flexible work in developing countries: Algorithmic management of work and workers. Competition and Change, 25(2), 212-236. doi:10.1177/1024529420905187

Ratten, V. (2021). COVID-19 and entrepreneurship: Future research directions. Strategic Change, 30(2), 91-98. doi:10.1002/ jsc. 2392

Ratten, V., \& Jones, P. (2021). Entrepreneurship and management education: Exploring trends and gaps. International Journal of Management Education, 19(1) doi:10.1016/j.ijme.2020.100431

Sestino, A., Prete, M. I., Piper, L., \& Guido, G. (2020). Internet of things and big data as enablers for business digitalization strategies. Technovation, 98 doi:10.1016/j.technovation.2020.102173

Shahi, C., \& Sinha, M. (2021). Digital transformation: Challenges faced by organizations and their potential solutions. International Journal of Innovation Science, 13(1), 17-33. doi:10.1108/IJIS-09-2020-0157

Sinha, S., \& Pradhan, C. (2021). Blockchain technology enabled digital identity management in smart cities doi:10.1007/978-3$030-53149-2 \_7$

Solozhentsev, E., \& Karasev, V. (2020). The digital management of structural complex systems in economics. International Journal of Risk Assessment and Management, 23(1), 54-79. doi:10.1504/IJRAM.2020.106163

Wiesböck, F., \& Hess, T. (2020). Digital innovations: Embedding in organizations. Electronic Markets, 30(1), 75-86. doi:10.1007/ s12525-019-00364-9

Wirtz, B. W., Müller, W. M., \& Weyerer, J. C. (2020). Digital pandemic response systems: A strategic management framework against covid-19. International Journal of Public Administration, doi:10.1080/01900692.2020.1858316

Wang, C., Horby, P. W., Hayden, F. G., \& Gao, G. F. (2020). A novel coronavirus outbreak of global health concern. Lancet (London, England), 395(10223), 470-473.

Wrede, M., Velamuri, V. K., \& Dauth, T. (2020). Top managers in the digital age: Exploring the role and practices of top managers in firms' digital transformation. Managerial and Decision Economics, 41(8), 1549-1567. doi:10.1002/mde.3202

Yankovskaya, V. V., Panko, I. V., Kruglyak, Z. I., Kolesnikov, A. V., \& Kosarev, V. E. (2020). Digital supply chain trends in the world economy. International Journal of Supply Chain Management, 9(4), 828-835.

Yousif Alsharidah, Y. M., \& Alazzawi, A. (2020). Artificial intelligence and digital transformation in supply chain management A case study in saudi companies. Paper presented at the 2020 International Conference on Data Analytics for Business and Industry: Way Towards a Sustainable Economy, ICDABI 2020, doi:10.1109/ICDABI51230.2020.9325616 